\title{
Creditworthiness Assessment for Credit Institutions and for the Risk Associated with Excessive Leverage toward Sustainable Performance
}

\author{
Razvan Sorin Șerbu ${ }^{1, *(\mathbb{D}}$, Laurentiu Paul Baranga ${ }^{2}$ and Ovidiu Gheorghe Petru ${ }^{3}$ \\ 1 Department of Management, Marketing and Business Administration, Faculty of Economic Sciences, Lucian \\ Blaga University of Sibiu, 550324 Sibiu, Romania \\ 2 Bucharest University of Economic Studies, 010374 Bucharest, Romania; barangalp@yahoo.com \\ 3 School of Advanced Studies of the Romanian Academy (SCOSAAR), Romanian Academy, 010071 Bucharest, \\ Romania; ovipetru@gmail.com \\ * Correspondence: razvan.serbu@ulbsibiu.ro; Tel.: +40-722247363
}

Citation: Șerbu, R.S.; Baranga, L.P.; Petru, O.G. Creditworthiness

Assessment for Credit Institutions and for the Risk Associated with Excessive Leverage toward Sustainable Performance. Sustainability 2021, 13, 11574. https:// doi.org/10.3390/su132111574

Academic Editor: Mike Tsionas

Received: 29 August 2021

Accepted: 6 October 2021

Published: 20 October 2021

Publisher's Note: MDPI stays neutral with regard to jurisdictional claims in published maps and institutional affiliations.

Copyright: (c) 2021 by the authors. Licensee MDPI, Basel, Switzerland. This article is an open access article distributed under the terms and conditions of the Creative Commons Attribution (CC BY) license (https:/ / creativecommons.org/licenses/by/ $4.0 /)$.

\begin{abstract}
With the development of financial transactions, it has become necessary for parties to assess the creditworthiness of their counterparty before entering into an agreement. In this respect, z-scoring methods for assessing creditworthiness have been developed, credit risks have been regulated, and rating providers have emerged to ensure a certain level of independence. This article introduces a z-scoring methodology, developed using principal component analysis, for assessing the creditworthiness of credit institutions; a methodology for determining the rating corresponding to the scoring obtained by the entities, developed through expert judgement; and an analysis of the existence of a significant correlation between z-scoring and the level of the leverage and capital adequacy ratios. Furthermore, considering that excessive leverage can have a negative impact on the creditworthiness of an entity, a methodology for assessing the leverage ratio is presented, along with a method for determining any additional own fund requirements where this ratio is above the regulated maximum level. The results obtained by applying the described methodologies to the data of the entities showed stable character. All these methodologies can be implemented by credit institutions to achieve better creditworthiness and business sustainability.
\end{abstract}

Keywords: leverage; additional funds requirement; risk level; sustainable financial markets; exposure increase techniques; capital adequacy ratio; z-scoring formula

\section{Introduction}

In any commercial or financial relationship in which the parties are exposed to certain risks arising from fulfilling their mutual obligations over a long period of time or in multiple stages, the creditworthiness of the business partners must be assessed. It is therefore necessary that, before signing a contract, the parties are aware of the impact and risk of failing to fulfil their obligations in due time so that they can implement measures and strategies to mitigate financial risks.

The main objective of this research was to identify a relevant methodology for assessing the financial security of credit institutions. To achieve this, these main sub-objectives were pursued: the development of a methodology for determining a z-scoring, identifying a methodology for rating, developing a method for determining the additional own funding requirement for those credit institutions that have an excessive level of leverage, and a test of the results obtained through an analysis.

One of the conclusions identified from our results was the necessity of a stable and relevant creditworthiness assessment methodology. The analysis showed that financial institutions must also have a solid method for the assessment of their own additional fund requirements for excessive levels of leverage. Without this, any creditworthiness 
assessment methodology is vulnerable to macroeconomic shocks due to the change of economic cycles, which can influence institution credit.

In the financial field, the possibility that a business partner may be unable to meet its obligations originates in the level of prolonged settlement of financial transactions in lending activity and in the level of financial asset portfolios where the issuer of financial instruments could go bankrupt or default. Credit risk assessment is a risk-management activity also used by financial market infrastructure entities, where different methodologies for assessing the creditworthiness of participants and/or clearing members of that clearing and settlement system are used to determine the level of contributions to the guarantee fund and/or to the margin fund.

For the above purposes, different methods or methodologies for assessing the credit risk of business partners are included in the risk-management activities of financial entities, and, depending on the outcome of the assessment, the entity adjusts its offer of financial services or products and the maximum levels of exposure to various individuals, financial entities, or issuers.

For the assessment of financial entities, the particularities of how that entity operates, which may have a negative impact on the financial stability, are also taken into account in credit-risk-assessment methodologies. Thus, in the credit risk assessment of credit institutions, indicators other than the financial, accounting, and prudential indicators are also considered, which may lead to an increase in the impact of risks to which the financial entity is exposed. Given that a credit institution uses resources attracted through deposits and/or debt instruments in its current business, the most important factor that can have a negative impact on prudential solvency is leverage.

Leverage acts as a factor that enhances the impact that credit risks and market risks could have on its own funds. The impact of this factor is greater when the leverage level is high. Sources of excessive leverage may be financial techniques and instruments through which the financial entity increases its financial exposure, which ultimately leads to the recording of a level of exposure much higher than could have been obtained by that financial entity placing its own resources in different financial assets.

The prudential legislation applicable to credit institutions has provided a methodology for determining the risk level corresponding to the leverage but has failed to establish a methodology for determining the additional own fund requirements if the level of such an indicator falls below 3\%.

This paper presents a methodology for assessing the creditworthiness of credit institutions, a methodology for assessing the risk corresponding to leverage, and a method for determining additional own fund requirements if the leverage level becomes very high.

These risk-management methodologies will translate to better sustainability if they are meticulously implemented by credit institutions.

Sustainability is an extremely important element in financial business and business in general because it involves the long-term consideration of as many social factors as possible, including future generations and the environment. Another reason why this analysis for the "assessment of the credit worthiness of credit institutions and of the risk associated with excessive leverage" is presented is because paying attention to the risk of credit and adopting sustainable principles will ensure the longevity of a business, not only its profits. The authors of this paper absolutely agree with the Fitch Ratings idea that evolving to further sustain an economy will permanently affect the financial institutions and their ratings in the long term.

In his article "Robo-Advising Risk Profiling through Content Analysis for Sustainable Development in the Hong Kong Financial Market", author Mike K. P. highlighted the strong connection between sustainability and credit risk, the same credit risk discussed in this paper. The authors of this paper aimed to study the measurement and reduction of credit risk in order to achieve the sustainability of investment products and services because a comprehensive risk assessment not only is a regulatory requirement but also 
builds trust and develops relationships with customers, as well as contributing to financial inclusion [1].

Abdul Razak and co-authors also noticed the growing concern over sustainability issues, an increasing demand to incorporate environmental and social issues into assessments of credit risk, and the possibility of loss resulting from a borrower's failure to meet their financial obligations. This paper also contributes to this concept, increasing attention to credit by presenting evidence of the relationship between sustainability measures and credit risk [2].

\section{Analyzed Literature}

In specialized literature, there are articles dealing with issues related to the likelihood of default, the assessment of the creditworthiness of financial entities, and the assessment of credit risk in the current risk management or prudential supervision activity carried out by the competent authorities.

In European legislation concerning prudential rules applicable to credit institutions, there are a number of rules and principles in addition to the Basel Accord for determining credit risk level and for using the ratings provided by large rating agencies or ratings determined by the entity internally in their risk-management activities by applying an advanced risk-assessment methodology that was previously authorized by the competent authority.

The determination of creditworthiness level is the first step towards estimating the probability of default of a financial entity, and starting from this result, credit-riskassessment methods can be developed. Over time, structural models have been developed based on the Merton Option Pricing Model and core models that focused on the financial and accounting indicators as determining factors. Within the latter category, macroeconomic models, credit scoring models, and rating models may be identified.

Credit scoring models have been developed based on various statistical and econometric methods used by many researchers, such as Beaver in 1966 [3] and Altman in 1968 [4,5], who tested the use of linear discriminatory analysis to predict a company's failure.

Paul Baranga and Iulian Panait (2018) in [6] discussed how a rating determination methodology applicable to non-bank financial entities could be built using a z-scoring approach.

The paper "Size, Leverage, and Risk-Taking of Financial Institutions" created a substantial literature review, a summary of other studies that examined the risk-taking behavior of financial institutions (see Saunders et al., 1990 [7]; Demsetz and Strahan, 1997 [8]; Stiroh, 2006 [9]; Laeven and Levine, 2009 [10]; Houston et al., 2010 [11]; Angier Deniz and Demirguc-Kunt, 2014 [12]) and the relation between size and risk-taking of financial institutions. In practice, financial institutions are faced with a wide variety of techniques and methods to increase the level of exposure above the level of Tier 1 own funds held, which increases the impact of other financial risks to which the financial entity is exposed [13].

Further titles and ideas from the paper "The Effect of Systematic Default Risk on Credit Risk Premiums" are noteworthy, as author Kim Jungmu asserts that despite existing credit risk events such as debt restructuring, bankruptcy, and payment default, any firm has the potential to affect not only their sustainability (in terms of assured incomes) but also that of the economy overall [14].

Additionally notable is the study of Dana Kisel'áková, Paulina Filip, Erika Onuferová, and Tomáš Valentiny, "The Impact of Monetary Policies on the Sustainable Economic and Financial Development in the Euro Area Countries" [15]; in accordance with Agenda 2030 for sustainable development that highlighted the concept of sustainable development based on three known pillars-sustainable economic growth, social inclusion, and environmental protection-that have been recognized as fundamental in the development processes of all the EU countries. As the supreme institution of the EU, the European Central Bank has a clear mandate-sustaining financial development and price stability in the EU using its monetary policies and mechanisms [15]. 
Halit Gonenc and Bert Scholtens studied the relationship between financial performance and responsibility in the banking industry. Given the wide diversity in business models and operations, this relationship needs to be studied at the level of specific industries [16].

The findings of Mamiza Haq and Richard Heaney showed that bank capital is negatively related to bank equity risk (with the exception of interest rate risk) and credit risk, suggesting that increased bank capital results in reduced risk. These findings shows that an adequately capitalized institution is a necessary but not sufficient condition to decrease risk [17].

At the same time, a study by Martin Hodula, Zlatuše Komárková, and Lukáš Pfeifer showed that in the declining phase of the cycle, when the authority relaxes the riskweighted capital requirement, it becomes crucial to monitor how restrictive other instruments are to reduce the risk of a significant decline in lending during a recession, which may occur due to a breach of a capital or liquidity standards [16-18].

In the study "The Vulnerabilities of the Risk Assessment Model Elaborated by the Basel Committee for Banking Supervision" Paul Baranga and Iulian Zalinca presented a methodology for determining the z-scoring for credit institutions used to identify vulnerabilities in the risk-management model used by the banking sector [19].

K. D'Hulster's 2009 study "Why 'Basel II' may need a leverage ratio restriction" [20] and J.M. Blumin's 2008 study [21] explained the need to introduce a leverage indicator into prudential legislation, while M. Grill, J.H. Lang, and J. Smith's 2015 study [22] presented the risk posed by a very high level of leverage on the stability of a bank. Similarly, in the study "The leverage ratio, risk-taking and bank stability", I. Kiema and E. Jokivuolle analyzed situations in which the leverage indicator contributes to the improvement of a bank's stability [23].

We mention here several hypotheses and research questions:

Hypothesis 1. We may find a way to satisfy the need to assess the default probability of counterparties in financial transactions in order to improve the credit risk and credit-risk-management models of the counterparty.

Hypothesis 2. We will start with data recorded by a sample of credit institutions, both from the financial statements and prudential reporting (internal capital adequacy assessment process (ICAAP) and the internal liquidity adequacy assessment process (ILAAP)), as well as (implicitly) from the qualitative evaluations of these data.

Hypothesis 3. By applying this method presented in this paper, we will fulfil the need to improve the model for determining the capital adequacy rate by identifying the main vulnerability and a way of managing the vulnerability.

Questions regarding our study include:

- What method should be used to assess and manage financial risks in order to improve risk management for these institutions while helping the system to be more stable and resilient and contributing to improving the sustainability of the banking industry?

- What methodology should we develop to help risk managers assess the probability of default of credit institutions?

- How can we develop a method to determine the rating for credit institutions such that risk-management activities can be completed through qualitative assessments?

- How can we help the risk-assessment system develop a methodology for determining the additional need for own funds in situations where the leverage ratio is higher than the one provided by regulations?

- How can we improve the risk assessment for banks defaults, and what techniques should we apply to reduce the impact of a risky leverage at the level of systemic risk management for this industry? 


\section{Materials and Methods}

European legislators have a set of prudential indicators and minimum limits for capital adequacy regulations to ensure sound financial stability for credit institutions [24]. At the same time, for certain risks, the prudential legislation applicable to credit institutions imposes an obligation to manage risks, report them to competent financial authorities, and permanently monitor them so that the capital adequacy ratio does not fall below a certain level. Below this level, the impact of those risks may negatively affect the stability of the credit institution, even if the rest of the indicators are maintained within the limits set by the applicable legislation [25-29].

For some of these indicators, in earlier versions of prudential legislation applicable to the banking sector, certain limits could not be exceeded (e.g., maximum exposure of $25 \%$ to a client), but subsequent versions of the prudential legislation allowed that limit to be exceeded, provided that the entity ensured an excess of own funds.

To determine the methodology for assessing the financial stability of credit institutions, we used the factor reduction method-main components analysis. Regarding the construction of the database, six financial indicators that are found in the financial balance sheet and six prudential indicators defined by capital adequacy legislation were considered.

Thus, when building the database, an attempt was made to take over the most relevant/important financial/prudential indicators that are used in the evaluation of credit institutions. Additionally, the factorial reduction procedure was used to obtain a KaiserMeyer-Olkin (KMO) level that was as good as possible given a small number of very relevant analyzed factors (rate of capital adequacy-because it is the most important indicator; the rate level one own funds-because its share shows the quality equity; level of leverage-shows the rate of depreciation of own funds in case of materialization of risks; profit and loss—-show the ability of the business to obtain returns, etc.). To be able to see the interconnections between these relevant indicators, the $\mathrm{z}$-scoring formula was used to added weighted " $X$ " values, the weights being determined by through the existing correlations between the indicators.

Following obtainment, the scoring values for each entity were taken into account while analyzing the distribution of the data and subsequently identifying the intervals of scoring for each rating level/PD by using expert judgment.

Regardless of the type of distribution used in the analysis and the method determination of z-scoring, expert judgments that consider, e.g., the rating comparison obtained by an entity against the result of a financial valuation (from financial accounting data) and prudential valuation (from the data of the indicators provided by capital adequacy legislation), are used when establishing scoring intervals.

Below, we explain two stages in developing methodologies for assessing the creditworthiness of credit institutions:

- $\quad$ Stage 1-develop a methodology to assess the creditworthiness of credit institutions and to determine a rating related to the likelihood that the bank will default.

- $\quad$ Stage 2-identify the most relevant risk that could have a negative impact on a credit institution's creditworthiness and build a methodology to assess that risk. At the same time, a method for determining the capital requirement corresponding to the analyzed risk is proposed.

\subsection{Stage 1-Methodology for Assessing Creditworthiness}

A methodology for developing a formula for determining the creditworthiness of credit institutions and implicitly for determining a rating for the likelihood that the bank will default is set out in the article "The Vulnerabilities of the Risk Assessment Model Elaborated by the Basel Committee for Banking Supervision" [19]. In view of developing a formula for determining the financial creditworthiness of credit institutions, we built a database containing the values of the most relevant prudential and financial-accounting indicators corresponding to a sample of nine credit institutions from Southeast Europe; the 
values included in the database were recorded by the relevant financial entities on seven reporting dates.

The rationale for selecting the indicators used in building the database, the method for selecting them, and the method by which certain missing or abnormal values were entered; the logic behind choosing the reporting deadlines; and the way in which the chosen indicators were prioritized (as well as other relevant aspects) were introduced in the article "Estimating the credit risk score for non-bank stock exchange intermediaries in the eventuality of changeover to euro currency" in 2018 [6].

After building the database containing the values of the most relevant prudential and financial-accounting indicators used in the banking sector by applying the principal component analysis method, we identified the z-scoring formula, which is most relevant in both statistical and economic terms. In the analyses and simulations carried out by using the principal component analysis method, the following criteria were taken into account:

- Any identified formula had to contain at least the capital adequacy ratio and the Tier 1 own funds.

- The identified formula had to be reasonable both in terms of risk management and economics (depending on the type of indicators and weighting factors included in that formula). The level of information contained by the main indicators envisaged must be as high as possible.

- The relevance test level of the data sample, assessed with the KMO test had to be as high as possible, but always above 0.60 points (to be statistically relevant).

- The formula had to contain an appropriate number of indicators so that the used data could be reasonably used in assessing a credit institution's activity both prudentially and from the financial-accounting point of view. The structure of the indicators used had be balanced between the prudential and the financial-accounting indicators.

Based on the above criteria, a number of simulations and analyses were carried out by removing one indicator at a time and/or by adding another indicator that led to a set of PCA analyses across a variety of combinations of data categories of the most relevant indicators. The best obtained z-scoring formula was:

$$
\begin{gathered}
\text { Z-scoring }=(0.915) * \mathrm{CAR}+(0.987) * \mathrm{~T} 1 \mathrm{OF}+(0.990) * \mathrm{TOF}+(0.930) * \mathrm{LER} \\
+(0.818) * \mathrm{P} \& \mathrm{~L}+(0.841) * \mathrm{TAV} .
\end{gathered}
$$

where:

- CAR - the value of the capital adequacy ratio/own funds ratio.

- $\mathrm{T1OF}$ - the variation of Tier 1 own funds.

- LER-the variation of leverage.

- P\&L-the variation of the value of the profit and loss account.

- $\quad$ TAV-the total asset variation.

Table 1 shows how to identify the z-scoring formula for credit institutions.

Table 1. Determination of the z-scoring formula *.

\begin{tabular}{ccccc}
\hline & \multicolumn{2}{c}{ Communalities } & \multicolumn{2}{c}{ Component Matrix } \\
\hline Indicator & Initial Value & $\begin{array}{c}\text { Value Resulting } \\
\text { from Extraction }\end{array}$ & Indicator & $\begin{array}{c}\text { Weighting } \\
\text { Factor }\end{array}$ \\
\hline CAR & 1 & 0.838 & CAR & 0.915 \\
T1OF & 1 & 0.974 & T1OF & 0.987 \\
TOF & 1 & 0.980 & TOF & 0.990 \\
LER & 1 & 0.864 & P\&L & 0.930 \\
P\&L & 1 & 0.670 & TAV & 0.818 \\
TAV & 1 & 0.707 & LER & 0.841 \\
\hline
\end{tabular}

*From authors' analyses. 
The result of the KMO test conducted on the data sample used to identify this z-scoring formula was 0.836 . Table 2 shows the statistical results of the KMO test.

Table 2. Results of Kaiser-Meyer-Olkin (KMO) and Bartlett's tests *.

\begin{tabular}{lcc}
\hline \multicolumn{2}{c}{ Kaiser-Meyer-Olkin Measure of Sampling Adequacy } & 0.836 \\
\hline \multirow{3}{*}{ Bartlett's Test of Sphericity } & approx. Chi-Square & 815.210 \\
\cline { 2 - 3 } & Df & 15 \\
& Sig. & 0.000 \\
\hline
\end{tabular}

*From authors' analyses.

The KMO test value of 0.836 was of good statistical relevance and showed that the $\mathrm{z}$-scoring formula could be useful for a long time span. The closer the KMO test value was to the 0.60 point level, the more frequently (e.g., quarterly) the tests had to be repeated. These tests were conducted on data collected at the same frequency.

The value of the Bartlett's test of sphericity was low, which led to the assumption that the analyzed indicators were correlated and also proved that the application of the factorial reduction procedure was justified. Table 3 shows some principal component analysis results.

Table 3. Extraction method: principal component analysis *.

\begin{tabular}{|c|c|c|c|c|c|c|}
\hline \multirow{2}{*}{ Indicator } & \multicolumn{3}{|c|}{ Initial Eigenvalues } & \multicolumn{3}{|c|}{ Extraction Sums of Squared Loadings } \\
\hline & Total & $\%$ of Variance & Cumulative $\%$ & Total & $\%$ of Variance & Cumulative $\%$ \\
\hline CAR & 5.033 & 83.883 & 83.883 & 5.033 & 83.883 & 83.883 \\
\hline T1OF & 0.484 & 8.069 & 91.952 & & & \\
\hline TOF & 0.306 & 5.096 & 97.048 & & & \\
\hline LER & 0.132 & 2.195 & 99.243 & & & \\
\hline P\&L & 0.044 & 0.732 & 99.975 & & & \\
\hline TAV & 0.001 & 0.025 & 100.000 & & & \\
\hline
\end{tabular}

In Table 3, it can be noticed that the CAR and LER indicators, the values of which were similar to the z-scoring formula, had a cumulative load of the information contained in the $86 \%$ dataset. Furthermore, the CAR indicator (which is the most important indicator in the capital adequacy methodology/legislation) showed the highest load of information included in the dataset of approximately $84 \%$.

A rating methodology for the assessment of credit institutions, depending on the level of the z-scoring obtained by applying the formula to the data recorded by those financial entities, was developed next. Thus, applying the formula to the data recorded by financial entities provided a string of data ranging between -8.8 and 9.1. The distribution of the z-scoring results is shown in Figure 1, with supplementary data shown in Appendix A.

Applying the statistical functions corresponding to the skewness and kurtosis indicators showed that this distribution was slightly negative in terms of asymmetry and had a peak twice higher than normal (leptokurtic distribution). The statistical parameters corresponding to the distribution of the z-scoring results are shown in Table 4.

Thus, the analysis of the statistical parameters corresponding to the distribution of the $\mathrm{z}$-scoring results showed that their distributions were almost symmetrical, and most values were grouped around the average value.

Furthermore, we set the scoring ranges, the probability of default, and their dynamics for each separate rating. To that effect, we decided that the value " 0 " belonged to the $\mathrm{z}$-scoring range corresponding to the "investment grade" attribute, namely from the "BBB" rating. At the same time, since the distribution of the z-scoring results was almost symmetrical, the scoring ranges were equal. 


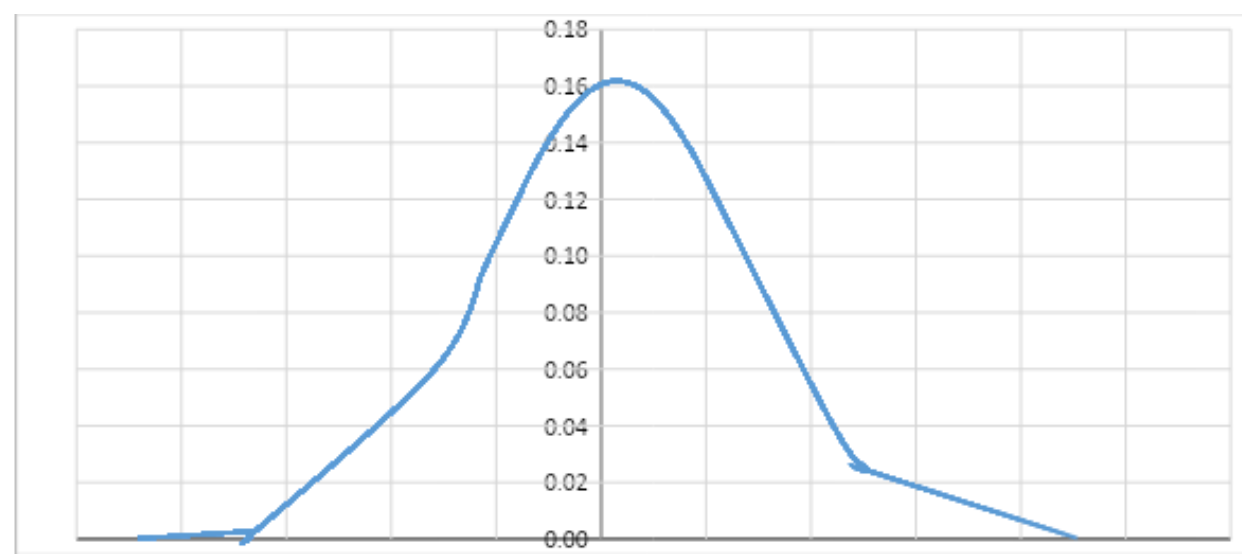

Figure 1. Distribution of the z-scoring results, from authors' analyses.

Table 4. Statistical parameters corresponding to the distribution of $\mathrm{z}$-scoring results *.

\begin{tabular}{ccc}
\hline Item No. & Indicator & Value \\
\hline 1 & $\begin{array}{c}\text { Number of values } \\
\text { Coefficient of asymmetry } \\
\text { (skewness) } \\
2\end{array}$ & 63 \\
3 & $\begin{array}{c}\text { Peakedness coefficient } \\
\text { (kurtosis) }\end{array}$ & -0.0456 \\
4 & Median & 6.056419 \\
5 & Standard deviation & 0.3013 \\
\hline
\end{tabular}

*From authors' analyses.

Table 5 shows the elements needed for determining the rating, the probability of default, and the associated risk level.

Table 5. Determination of the rating depending on the credit institution's z-scoring *.

\begin{tabular}{|c|c|c|c|c|}
\hline Rating & PD & $P D+X \%$ & z-Scoring Range & Associated Risk Level \\
\hline AAA & $0 \%$ & 1 & Above 20.00 & \multirow{7}{*}{ Very low risk } \\
\hline $\mathrm{AA}+$ & $1 \%$ & 1 & 18.00-20.00 & \\
\hline AA & $2 \%$ & 1 & $16.00-18.00$ & \\
\hline AA- & $3 \%$ & 1 & $14.00-12.00$ & \\
\hline $\mathrm{A}+$ & $4 \%$ & 2 & $12.00-10.00$ & \\
\hline A & $6 \%$ & 2 & $10.00-8.00$ & \\
\hline A- & $8 \%$ & 4 & $8.00-6.00$ & \\
\hline $\mathrm{BBB}+$ & $12 \%$ & 4 & $6.00-4.00$ & \multirow{3}{*}{ Low risk } \\
\hline BBB & $16 \%$ & 4 & $4.00-2.00$ & \\
\hline BBB- & $20 \%$ & 6 & $2.00-0.00$ & \\
\hline $\mathrm{BB}+$ & $26 \%$ & 6 & $0.00-(-2.00)$ & \multirow{3}{*}{ Medium risk } \\
\hline $\mathrm{BB}$ & $32 \%$ & 6 & $(-2.00)-(-4.00)$ & \\
\hline BB- & $38 \%$ & 6 & $(-4.00)-(-6.00)$ & \\
\hline $\mathrm{B}+$ & $42 \%$ & 8 & $(-6.00)-(-8.00)$ & \multirow{3}{*}{ High risk } \\
\hline B & $50 \%$ & 8 & $(-8.00)-(-10.00)$ & \\
\hline B- & $58 \%$ & 8 & $(-12.00)-(-14.00)$ & \\
\hline $\mathrm{CCC}+$ & $66 \%$ & 8 & $(-14.00)-(-16.00)$ & \multirow{6}{*}{ Very high risk } \\
\hline $\mathrm{CCC}$ & $74 \%$ & 8 & $(-16.00)-(-18.00)$ & \\
\hline $\mathrm{CCC}-$ & $82 \%$ & 8 & $(-18.00)-(-20.00)$ & \\
\hline CC & $90 \%$ & 8 & $(-20.00)-(-22.00)$ & \\
\hline $\mathrm{C}$ & $98 \%$ & 2 & $(-22.00)-(-24.00)$ & \\
\hline $\mathrm{D}$ & $100 \%$ & & below $(-24.00)$ & \\
\hline
\end{tabular}

*From authors' analyses. 
Next, the rating for each analyzed credit institution was determined for seven reporting dates. The ratings obtained for the analyzed credit institutions corresponding to the time interval for the seven reporting dates are shown in Table 6.

Table 6. Ratings obtained for the analyzed entities *

\begin{tabular}{|c|c|c|c|c|c|c|c|c|}
\hline Entity & T0 & $T+1$ & $\mathrm{~T}+2$ & $T+3$ & $T+4$ & $T+5$ & $T+6$ & Risk Level T + 6 \\
\hline 1 & BBB- & BBB- & BBB- & BBB- & $\mathrm{BB}+$ & $\mathrm{BBB}+$ & $\mathrm{BB}+$ & Medium risk \\
\hline 2 & $\mathrm{BB}+$ & BBB- & $\mathrm{BB}+$ & $\mathrm{BB}$ & BBB- & $\mathrm{BB}+$ & $\mathrm{BB}$ & Medium risk \\
\hline 3 & BBB- & BBB- & $\mathrm{BB}+$ & $\mathrm{BB}+$ & $\mathrm{BB}+$ & BBB & $\mathrm{BB}+$ & Medium risk \\
\hline 4 & $\mathrm{BB}$ & $\mathrm{BB}$ & $\mathrm{BB}+$ & $\mathrm{BB}$ & $\mathrm{BB}+$ & BBB- & BBB- & Low risk \\
\hline 5 & BBB- & BBB- & $\mathrm{BB}+$ & BBB- & $\mathrm{BB}+$ & BBB- & $\mathrm{BB}+$ & Medium risk \\
\hline 6 & BBB- & BBB- & $\mathrm{BB}+$ & BBB- & BBB- & $\mathrm{BB}+$ & $\mathrm{BB}$ & Medium risk \\
\hline 7 & $\mathrm{BB}+$ & BBB- & $\mathrm{BB}+$ & BBB- & $\mathrm{BB}+$ & BBB- & $\mathrm{BB}+$ & Medium risk \\
\hline 8 & BBB & $\mathrm{BBB}$ & BBB & $\mathrm{BBB}$ & $\mathrm{BBB}$ & BBB & BBB & Low risk \\
\hline 9 & BBB- & BBB & BBB- & $\mathrm{BB}+$ & BBB- & BBB- & BBB- & Low risk \\
\hline
\end{tabular}
Table 7.

The dynamics of ratings obtained for the analyzed credit institutions are shown in

Table 7. Dynamics of the ratings obtained for the analyzed entities *.

\begin{tabular}{cccccccc}
\hline Entity & T+6 & Risk Level T + 6 & T + 5 & PD & T + 6 & PD & Dynamics \\
\hline 1 & BB+ & Medium risk & BBB+ & $12 \%$ & BB+ & $26 \%$ & $\downarrow$ \\
2 & BB & Medium risk & BB+ & $26 \%$ & BB & $32 \%$ & $\downarrow$ \\
3 & BB+ & Medium risk & BBB & $16 \%$ & BB+ & $26 \%$ & $\downarrow$ \\
4 & BBB- & Low risk & BBB- & $20 \%$ & BBB- & $20 \%$ & $=$ \\
5 & BB+ & Medium risk & BBB- & $20 \%$ & BB+ & $26 \%$ & $\downarrow$ \\
6 & BB & Medium risk & BB+ & $26 \%$ & BB & $32 \%$ & $\downarrow$ \\
7 & BB+ & Medium risk & BBB- & $20 \%$ & BB+ & $26 \%$ & $\downarrow$ \\
8 & BBB & Low risk & BBB & $16 \%$ & BBB & $16 \%$ & $=$ \\
9 & BBB- & Low risk & BBB- & $20 \%$ & BBB- & $20 \%$ & $=$ \\
* From authors' analyses. & & & & &
\end{tabular}

As can be seen from Table 6, the situation of the analyzed financial entities was stable and most of them qualified as "investment grade". Additionally, between reporting dates $\mathrm{T}+5$ and $\mathrm{T}+6$, most of the analyzed financial entities experienced a decrease in their creditworthiness.

\subsection{Testing of the Methodology for Assessing Creditworthiness}

In order to test the methodology for assessing the creditworthiness of credit institutions, stress tests and tests based on historical data were carried out. For this purpose, the observations recorded on the last reporting date were removed from the database, and the PCA simulation was subsequently repeated on the resulting sample of data for the same indicators as those envisaged at the original extraction. The obtained result was similar to the originally recorded one, with the KMO value decreasing by only a few hundredths of a point.

In addition, the value of the KMO test (i.e., 0.836) showed good statistical relevance and suggested the high usefulness of the z-scoring formula in practical activities since, by applying a stress value of $25 \%$, the result of this test continued to be above the minimum required level for statistical relevance.

\subsection{Stage 2-Methodology for Assessing Leverage-Induced Risk}

Given that the leverage effect acts as a factor that increases the impact that financial risks may have on own funds, it follows that it ultimately impacts the level of the capital adequacy ratio by reducing it to below the minimum regulatory level in the event that the financial risks of such an entity materialize. Thus, any technique to assess the impact of excessive leverage needs to consider both the regulatory minimum level established 
for this prudential indicator and the regulatory minimum level established for the capital adequacy ratio.

To that effect, we envisaged two scenarios:

- Scenario 1-where we analyzed the correspondence between the regulatory minimum levels of capital adequacy for the two prudential indicators-i.e., between leverage and capital adequacy ratio.

- Scenario 2-where we analyzed the correspondence between the optimal/prudent levels observed/identified in the current business of credit institutions for the two prudential indicators, i.e., between leverage and capital adequacy ratio.

In the first scenario, we considered a capital adequacy ratio of $8 \%$ and a leverage ratio of $3 \%$. Thus, for a capital adequacy ratio of less than $8 \%$, that financial entity would be exposed to an imminent risk of bankruptcy. Additionally, a leverage ratio of below 3\% is unsustainable for a credit institution. By determining the ratio between the statutory minimum levels established for leverage and the capital adequacy ratio, we obtained a value of 0.375 .

In the second scenario, we considered a capital adequacy ratio of $8 \%$ and a leverage ratio of $10 \%$. This is a prudent level, given that a credit institution is a financial entity that primarily works with financial resources attracted through deposits or other financial instruments issued for that purpose. A capital adequacy ratio of greater than $8 \%$ occurs when a credit institution has more own funds than it needs in order to cover potential financial losses (capital buffers) or has a prudent approach to risk management.

Additionally, in this scenario, we considered two aspects: (i) from what level the leverage is significant and must therefore be monitored and (ii) from what level the leverage becomes excessive, i.e., the risk manager must calculate additional own fund requirements.

Leverage becomes significant when the indebtedness ratio of the financial entity is greater than $66 \%$. At the same time, the leverage level becomes excessive when this financial entity experiences a ratio between the regulatory minimum levels of leverage and a capital adequacy ratio of less than 0.375 , which is a level derived from the reporting of the regulatory minimum levels established for the two prudential indicators.

Next, after determining the ratio between the prudent levels considered for the two indicators, we obtained a result of 1.25. Dividing the gap by four tolerance intervals resulted in a tolerance range of 0.21875 . The level of the impact of leverage on own funds must be adjusted by the level of capital buffers that the entity is required to maintain as a result of the decisions of competent authorities. Thus, in order for capital buffers to be able to attain the objective of catalyzing a possible impact, the factors that could increase that impact must not be covered by the excess of own funds required for creating those capital buffers.

Considering this, when calculating leverage, the financial entity must not use the entire value of Tier 1 own funds when determining the ratio between this indicator and the aggregate value of exposure; the entity must only use the amount that exceeds the Tier 1 own funds used for creating such capital buffers.

\subsection{Risk Panel for Leverage}

Furthermore, based on the ideas outlined in the methodology for assessing the risk corresponding to excessive leverage, we built a risk panel for leverage, as shown in Table 8 . Depending on the risk-management policy, risk panels covering five, four, or three risk levels can be built. At the same time, to identify the level of a particular risk, both equal and decreasing tolerance ranges may be used in financial entities. 
Table 8. Risk panel for leverage*.

\begin{tabular}{cccccc}
\hline $\begin{array}{c}\text { Tolerance } \\
\text { Range }\end{array}$ & $\begin{array}{c}\text { Very Low } \\
\text { Risk Level }\end{array}$ & $\begin{array}{c}\text { Low Risk } \\
\text { Level }\end{array}$ & $\begin{array}{c}\text { Medium } \\
\text { Risk Level }\end{array}$ & $\begin{array}{c}\text { High Risk } \\
\text { Level }\end{array}$ & $\begin{array}{c}\text { Very High } \\
\text { Risk Level }\end{array}$ \\
\hline LER/CAR & $1.25-1.032$ & $1.032-0.814$ & $0.814-0.596$ & $0.596-0.375$ & $\begin{array}{c}\text { Less than } \\
0.375\end{array}$ \\
\hline LER & $33-8.25 \%$ & $8.25-6.5 \%$ & $6.5-4.75 \%$ & $4.75-3 \%$ & Less than $3 \%$ \\
\hline *From authors' analyses.
\end{tabular}

* From authors' analyses.

When the leverage level falls below the minimum level of 3\%, risk managers must additionally determine an additional own fund requirement to consider when determining the capital adequacy ratio. As such, we identified a formula to determine the additional own fund requirements that would cover the impact of excessive leverage.

\section{Formulas and Discussion}

The impact that leverage can have on the level of credit and market risks, and implicitly on own funds, can be indirectly determined, i.e., by maintaining the prudential solvency of that financial entity and leverage at the minimum level required by prudential legislation.

4.1. Formula for Determining the Additional Own Funds Requirement to Cover the Impact of a Very High Leverage Level

By maintaining prudential solvency and leverage at the minimum levels imposed by the applicable legislation, the additional own fund requirements are determined as follows:

$$
\text { LER * }(1+\text { Fs }) / C A R=0.375 \text { or Fs }=(0.375 * \text { CAR }- \text { LER }) / L E R
$$

If the financial entity is required to maintain one or more capital buffers in determining their additional own funds requirement, the capital adequacy ratio adjustment factors shown in Table 9 must be considered.

Table 9. Level of the adjustment factor depending on the cumulative level of capital buffers absorbers or capital excess *.

\begin{tabular}{ccccccccc}
\hline CAR & $\mathbf{9 \%}$ & $\mathbf{1 0} \%$ & $\mathbf{1 1} \%$ & $\mathbf{1 2} \%$ & $\mathbf{1 3} \%$ & $\mathbf{1 4 \%}$ & $\mathbf{1 5 \%}$ & $\mathbf{1 6 \%}$ \\
\hline Buffer/excess & $1 \%$ & $2 \%$ & $3 \%$ & $4 \%$ & $5 \%$ & $6 \%$ & $7 \%$ & $8 \%$ \\
Adjustment factor & 0.333 & 0.300 & 0.272 & 0.250 & 0.230 & 0.214 & 0.200 & 0.188 \\
\hline *'From authors' analyses & & & & & &
\end{tabular}

According to the results presented in Table 9, the formula for determining the excess own funds to cover the impact of a very high (excessive) leverage level is as follows:

$$
\mathrm{Fs}=(\mathrm{Faj} * \mathrm{CAR}-\mathrm{LER}) / \mathrm{LER}
$$

where:

- Fs-amount by which the Tier 1 own funds level must be supplemented.

- Faj-size of the adjustment factor CAR, depending on the level of the capital buffer to be maintained by that financial entity.

- CAR - level of the capital adequacy ratio experienced by the financial entity.

- LER-leverage level experienced by the financial entity.

The obtained results are adjusted depending on the particularities derived from the risk-management policy of that financial entity.

\subsection{Adjustment of the Additional Own Funds Requirement to the Particularities Deriving from} the Risk-Management Policy

In applying this formula to calculate the excess of own funds intended for covering the impact of leverage, whether a capital adequacy ratio above the $8 \%$ level is due to a 
factual situation or to a risk-management policy that is self-imposed or required by any financial authority must be considered. The share of the Tier 1 own funds indicator in the total amount of own funds must also be considered.

When a financial entity has a capital adequacy ratio above the regulatory minimum level, efforts must be made to cover the impact of excessive leverage, the adjustment factor relevant to the level of this prudential indicator, in calculating own fund excess.

Once the own funds surplus is determined, the level of capital buffer that the financial entity has to maintain is deducted from the level of the capital adequacy ratio. Following this result, the share of Tier 2 own funds is deducted from the total own funds.

Subsequently, the weight of the items deducted from the capital adequacy ratio recorded by the entity is determined, and this weight is applied to the percentage of the Tier 1 additional own funds requirement as a factor to increase it due to the particularities derived from the risk-management policy of that financial entity.

In addition, when the leverage level drops below $3 \%$, the z-scoring formula is as follows:

$$
\begin{gathered}
\mathrm{z} \text {-scoring }=(0.915) * \mathrm{CAR}+(0.987) * \mathrm{~T} 1 \mathrm{OF}+(0.990) * \mathrm{TOF}+(0.930) \\
*\left(\mathrm{Faj}{ }^{*} \mathrm{CAR}-\mathrm{LER}\right) / \mathrm{Fs}+(0.818) * \mathrm{P} \& \mathrm{~L}+(0.841) * \mathrm{TAV} .
\end{gathered}
$$

In consideration of the minimum level of leverage effect required by law, the formula for determining the z-scoring must contain the minimum correlation levels between CAR and LER considered by the legislator.

\subsection{Certification and Calibration of the Risk-Assessment Methodology}

At this stage, we look at the correlation between the scoring levels and the determined levels of the ratio between the leverage ratio and the capital adequacy ratio of the nine credit institutions for the seven reporting dates.

The correlation between creditworthiness and the level of the leverage and capital adequacy ratios is shown in Figure 2.

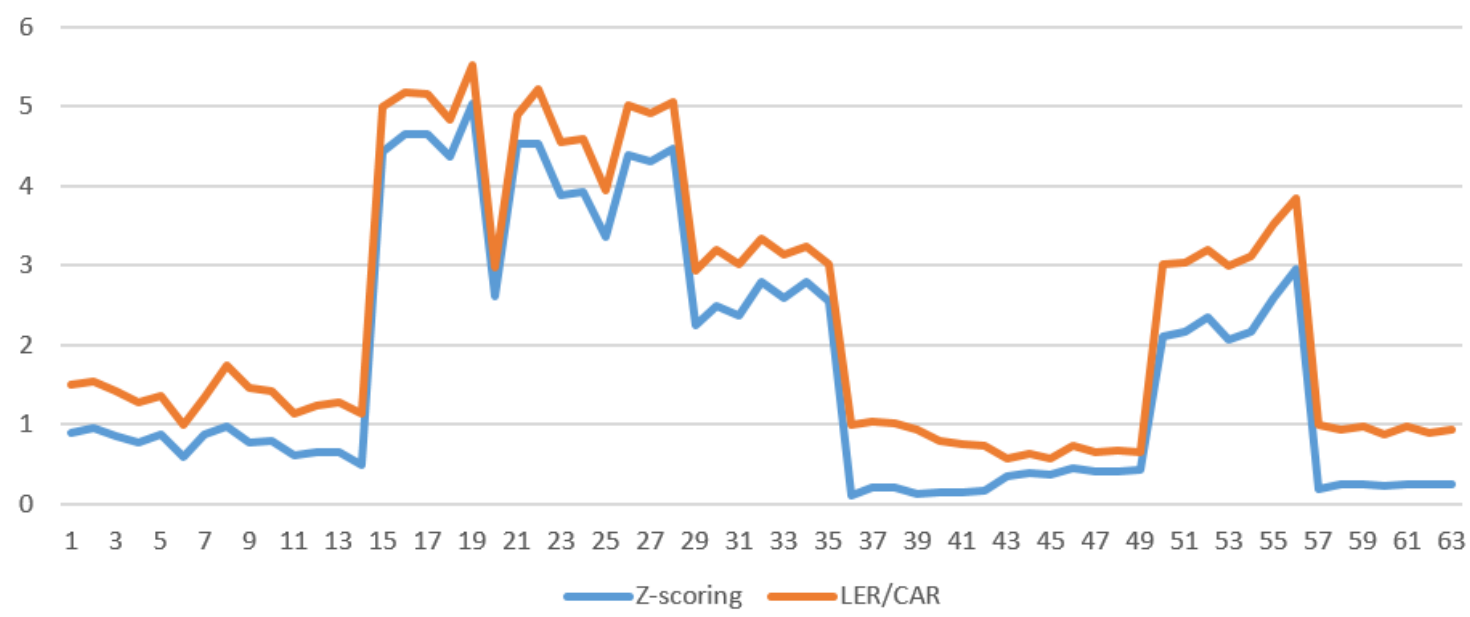

Figure 2. Correlation between financial creditworthiness and the LER/CAR level, from authors' analyses.

As can be seen in Figure 1, there was a high correlation between the financial creditworthiness of credit institutions and the level between the leverage and capital adequacy ratios. Given that these results were obtained by using data registered by a sample of credit institutions, we can conclude that one can verify and calibrate the methodology for assessing the level of risk associated with an excessive leverage level by using the ratios between leverage capital adequacy.

We developed a method for determining the rating for credit institutions that enables the completion of qualitative assessments during risk-management activities, and we 
also managed to support the risk-assessment system by developing a methodology for determining the additional need for own funds in situations where the leverage rate effect is higher than that provided by regulations.

Following the analysis of the two data categories, starting from the risk levels associated with creditworthiness, the value ranges corresponding to the leverage level were modified/adjusted to achieve the highest possible correlation between the risk levels corresponding to the two indicator categories. A risk panel adjusted for leverage risk is shown in Table 10.

Table 10. Risk panel adjusted for leverage risk *

\begin{tabular}{cccccc}
\hline $\begin{array}{c}\text { Tolerance } \\
\text { Range }\end{array}$ & $\begin{array}{c}\text { Very Low } \\
\text { Risk Level }\end{array}$ & $\begin{array}{c}\text { Low Risk } \\
\text { Level }\end{array}$ & $\begin{array}{c}\text { Average } \\
\text { Risk Level }\end{array}$ & $\begin{array}{c}\text { High Risk } \\
\text { Level }\end{array}$ & $\begin{array}{c}\text { Very High } \\
\text { Risk Level }\end{array}$ \\
\hline LER/CAR & $1.25-0.875$ & $0.875-0.650$ & $0.650-0.475$ & $0.475-0.375$ & Less than 0.375 \\
LER & $33-7 \%$ & $6.9-5.2 \%$ & $5.1-3.8 \%$ & $3.7-3 \%$ & Less than $3 \%$ \\
\hline *From authors' analyses. & & & &
\end{tabular}

The high correlation between the credit institutions' creditworthiness and the level between the leverage and capital adequacy ratios certifies the assumptions and proposal regarding the risk-assessment methodology corresponding to leverage. Additionally, by using the results of the methodology for assessing creditworthiness, which were obtained using actual data, the ranges of values corresponding to the leverage level were calibrated/adjusted such that they could be useful in the practical activity of risk management.

\section{Conclusions}

Our methodology for assessing the risks corresponding to leverage includes a method for determining the level of risk corresponding to this prudential indicator and a method for determining the additional own funds requirement to cover the impact of this risk. We have additionally presented a risk switchboard structure relevant to leverage, with possible ranges of this prudential indicator.

Simultaneously, we outlined a methodology for assessing the creditworthiness of credit institutions that includes, inter alia, a rating system and a method for determining the risk level corresponding to creditworthiness.

This stable methodology was obtained, and it can be used in practice for determining the own funding requirements for excessive levels of leverage.

The benefits of the two risk-assessment methodologies-the methodology corresponding to excessive leverage and the methodology corresponding to creditworthiness-are as follows: both methodologies are applicable in the risk-management activities of credit institutions. These methodologies can also be used in the prudential supervisory activity carried out in central banks or in other financial supervisory authorities.

These methodologies can be independently used or be further improved by analyzing the results obtained through simulations based on the data recorded on the reporting dates. Thus, these methodologies can be used by both risk managers within financial entities and specialists within financial supervisory authorities to improve the risk-assessment methodologies/supervisory procedures or as standalone methodologies/procedures. The methodologies can be improved depending on the judgement or other objectives of the risk managers/specialists within the financial supervisory authorities.

The methodology for assessing the risk of excessive leverage can also be improved depending on the methods for determining the total exposure recorded by the financial entity.

The methodology for assessing creditworthiness may also be used by risk-management specialists within other financial entities, provided that it is adapted to the specificity and particularities of those entities. These risk-assessment methodologies can easily be adapted to the level of other types or categories of financial entities, both as standalone methods and as tools for calibrating other risk-assessment methods. 
These risk-management methodologies can contribute to more sustainable businesses if implemented by credit institutions.

The following conclusions were derived from the results of the creditworthiness assessment methodology following the simulation of the data recorded by the financial entities.

Methodologies for assessing creditworthiness should be separately developed for each category of financial entity in order for that methodology to be able to incorporate legislative, operational, and building features for business lines, financial services, and products offered to the target group of clients/investors.

Within each category of financial entity, the methodologies for assessing creditworthiness must be separately developed for each sample of homogeneous entities. Thus, in order to consider the particularities of business lines for financial entities of the same type, which may include the option of authorization for one or all the activities provided for by law, separate methodologies need to be developed in order to ensure that the risk-management results are as relevant as possible.

If one or more entities concentrate most of their market share in the methodologies for assessing creditworthiness in the sample of financial entities under consideration, the indicators that incorporate that market share will not be considered; if considered, the analysis of these indicators will not be conducted using the absolute value, and a percentage value determined in relation to another indicator will be used. Our main objective was to develop a methodology for assessing the financial soundness of credit institutions that can be used in the practical activity of risk management. Our sub-objectives were to develop a z-scoring methodology and a method for classifying credit institutions that can provide stable and reliable results. In order to consolidate the results of the first two sub-objectives, we had to pursue another one to identify a methodology for assessing the surplus of own funds when the leverage exceeds the maximum level provided by regulations, as this excessive leverage may act as a major factor in the rapid deterioration of the financial stability of a credit institution. Moreover, because the development of the methodology for determining the additional own funds for excessive levels of leverage was considered to maintain the prudential balances considered by the working group that developed the Basel Accords, correlations between the results were analyzed by applying the identified z-scoring formula and the ratio between the leverage effect and the capital adequacy ratio.

The results of applying the identified z-scoring formula and the method for classifying credit institutions were stable and comparable to those we could obtain from a qualitative assessment. Additionally, by applying the methodology for determining the additional own fund requirements for excessive levels of leverage in risk-management activities, the classification methodology of credit institutions was provided a better applicability in the assessment of financial counterparties.

When establishing the scoring intervals for each rating, the expert judgement applied to the distribution characteristics of z-scoring results was also considered. In the future, we consider it necessary to use more advanced distribution analysis methods to provide a better view of extreme data in the left tail. In this regard, we intend to introduce the Student's $t$ copula functions when establishing the classification of credit institutions.

Because the assessment of the dependence between the factors included in the $\mathrm{z}$ scoring formula (which characterize the financial dynamics of a credit institution) becomes critical for assessing the performance of the entity, a measure is needed to correctly assess the dependence between them.

Thus, we propose the calculation of a matrix for the rank of correlation with Kendall for the factors of the z-scoring formula. The next step estimates the rho matrix of corresponding parameters for a Student's $t$ copula function with five degrees of freedom that have a dependency matrix of the previously estimated rank. To estimate a copula function, Student's $t$ data are transformed into the scale of the copula function (data with unit length) using a kernel that estimates the cumulative distribution function. A kernel distribution 
produces a nonparametric estimate of the distribution function that adapts the data to an arbitrarily imposed parametric distribution.

The cumulative distribution of the copula function (CDF function) represents its probability at the evaluated points in the data. From an economic point of view, the dependence between the factors included in the z-scoring formula takes a single value that depends on all the factors evaluated by the function at the same time. The more values a credit institution has in the left tail of the distribution, depending on the dependency between them, the lower the cumulative value of their marginal probabilities.

By ordering the values obtained according to the CDF, we could obtain an order in a certain classification for the analyzed entities.

In terms of limitations, neither the methodology for assessing creditworthiness nor the methodology for assessing the risk of excessive leverage can be used by risk managers for assessing and managing risks in financial entities without legal personality, such as pension funds or investment funds. This is because both methodologies consider the prudential solvency indicator, which is found in financial entities with legal personality.

Author Contributions: Conceptualization, L.P.B. and O.G.P.; methodology, R.S.S., L.P.B. and O.G.P.; literature overview, R.S.Ș. and L.P.B.; data collection L.P.B. and O.G.P.; data curation, L.P.B.; writing review and editing, R.S.S. and O.G.P.; supervision, R.S.S. All authors have read and agreed to the published version of the manuscript.

Funding: This research received no external funding.

Institutional Review Board Statement: Not applicable.

Data Availability Statement: Data are contained within the article and Appendix A; https://doi. org/10.17632/kb66phbckw.1.

Conflicts of Interest: The authors declare no conflict of interest.

\section{Appendix A}

SERBU, Razvan; BARANGA, Paul; PETRU, Ovidiu (2021), “Appendix A_Supplementary Data", Mendeley Data, V1, https://doi.org/10.17632/kb66phbckw.1.

\section{References}

1. So, M.K.P. Robo-Advising Risk Profiling through Content Analysis for Sustainable Development in the Hong Kong Financial Market. Sustainability 2021, 13, 1306. [CrossRef]

2. Abdul Razak, L.; Ibrahim, M.H.; Ng, A. Which Sustainability Dimensions Affect Credit Risk? Evidence from Corporate and Country-Level Measures. J. Risk Financ. Manag. 2020, 13, 316. [CrossRef]

3. Beaver, W.H. Financial ratios as predictors of failure. J. Account. Res. 1966, 71-111. [CrossRef]

4. Altman, E.; Sabato, G. Effects of the New Basel Capital Accord on Bank capital Requirements for SMEs. J. Financ. Serv. Res. 2005, 28, 15-42. [CrossRef]

5. Altman, E.; Sabato, G. Modeling Credit Risk for SMEs: Evidence from US Market. SSRN Work. Pap. Financ. Stud. 2005, 39. [CrossRef]

6. Baranga, P.; Panait, I. Estimating the credit risk score for non-bank stock exchange intermediaries in the eventuality of changeover to euro currency. Financ. Stud. 2018, 22, 25-40.

7. Saunders, A.; Elizabeth, S.; Travlos, G. Ownership structure, deregulation, and bank risk-taking. J. Financ. 1990, 45, 643-654. [CrossRef]

8. Demsetz, R.S.; Strahan, E. Diversification, size, and risk at bank holding companies. J. Money Credit Bank. 1997, $29,300-313$. [CrossRef]

9. Stiroh, K. New evidence on the determinants of bank risk. J. Financ. Serv. Res. 2006, 30, 237-263. [CrossRef]

10. Laeven, L.; Levine, R. Bank governance, regulation and risk-taking. J. Financ. Econ. 2009, 93, 259-275. [CrossRef]

11. Houston, J.; Lin, C.; Lin, P.; Ma, Y. Creditor rights, information sharing, and bank risk-taking. J. Financ. Econ. 2010, 96, 485-512. [CrossRef]

12. Anginer, D.; Demirguc, K. Has the global banking system become more fragile over time? J. Financ. Stab. 2010, 13, 202-213. [CrossRef]

13. Bhagat, S.; Bolton, B.; Lu, J. Size, leverage, and risk-taking of financial institutions. J. Bank. Financ. 2015, 59, 520-537. [CrossRef]

14. Kim, J. The Effect of Systematic Default Risk on Credit Risk Premiums. Sustainability 2019, 11, 6039. [CrossRef] 
15. Kisel'áková, D.; Filip, P.; Onuferová, E.; Valentiny, T. The Impact of Monetary Policies on the Sustainable Economic and Financial Development in the Euro Area Countries. Sustainability 2020, 12, 9367. [CrossRef]

16. Gonenc, H.; Scholtens, B. Responsibility and Performance Relationship in the Banking Industry. Sustainability 2019, 11, 3329. [CrossRef]

17. Haq, M.; Heaney, R. Factors Determining European Bank Risk. SSRNS Elibrary 2011. [CrossRef]

18. Hodula, M.; Komárková, Z.; Pfeifer, L. The relationship between capital and liquidity prudential instruments. J. Regul. Econ. 2021, 59, 47-70. [CrossRef]

19. Baranga, P.; Zalinca, I. The Vulnerabilities of the Risk Assessment Model Elaborated by the Basel Committee for Banking Supervision. In Business Revolution in a Digital Era; Springer: Cham, Switzerland, 2021. [CrossRef]

20. D'Hulster, K. The Leverage Ratio: A New Binding Limit on Banks; Crisis Response Note, World Bank Nowledge Notes, No. 11; World Bank: Washington, DC, USA, 2009. Available online: https:/ /openknowledge.worldbank.org/handle/10986/10224 (accessed on 5 July 2021).

21. Blum, J. Why 'Basel II' may need a leverage ratio restriction. J. Bank. Financ. 2008, 32, 1699-1707. [CrossRef]

22. Grill, M.; Lang, J.; Smith, J. The leverage ratio, risk-taking and bank stability. Financ. Stab. Rev. 2020. [CrossRef]

23. Kiema, I.; Jokivuolle, E. Does a leverage ratio requirement increase bank stability? J. Bank. Financ. 2014, 39, 240-254. [CrossRef]

24. Bandyopadhyay, A. Predicting probability of default of Indian corporate bonds: Logistic and Z-score model approaches. J. Risk Financ. 2006, 7, 255-272. [CrossRef]

25. Directive 2013/36/EU of the European Parliament and of the Council of 26 June 2013 on Access to the Activity of Credit Institutions and the Prudential Supervision of Credit Institutions and Investment Firms, Amending Directive 2002/87/EC and Repealing Directives 2006/48/EC and 2006/49/EC. Available online: https:/ / eur-lex.europa.eu/LexUriServ/LexUriServ.do?uri=OJ:L:2013: 176:0338:0436:En:PDF (accessed on 5 July 2021).

26. Regulation (EU) No. 575/2013 of the European Parliament and of the Council of 26 June 2013 on Prudential Requirements for Credit Institutions and Investment Firms and Amending Regulation (EU) No 648/2012. Available online: https: / / eur-lex.europa. eu/legal-content/EN/TXT/?uri=celex\%3A32013R0575 (accessed on 5 July 2021).

27. Commission Implementing Regulation (EU) 2016/428 of 23 March 2016 Amending Implementing Regulation (EU) No. 680/2014 Laying Down Implementing Technical Standards with Regard to Supervisory Reporting of Institutions as Regards the Reporting of the Leverage Ratio. Available online: https:/ / eur-lex.europa.eu/legal-content/en/ALL/?uri=CELEX\%3A32016R0428 (accessed on 21 June 2021).

28. Commission Implementing Regulation (EU) 2016/200 of 15 February 2016 Laying Down Implementing Technical Standards with Regard to Disclosure of the Leverage Ratio for Institutions, According to Regulation (EU) No. 575/2013 of the European Parliament and of the Council. Available online: https:/ / eur-lex.europa.eu/legal-content/EN/TXT/?uri=CELEX\%3A32016R066 4 (accessed on 21 June 2021).

29. Commission Delegated Regulation (EU) 2015/62 of 10 October 2014 Amending Regulation (EU) No. 575/2013 of the European Parliament and of the Council with Regard to the Leverage Ratio. Available online: https: / / eur-lex.europa.eu/legal-content/ EN/TXT/PDF/?uri=CELEX:32015R0062\&from=DE (accessed on 5 July 2021). 